\title{
Talking about College Students' Innovation and Pioneering Education
}

\author{
Jian $\mathrm{Wu}{ }^{\mathrm{a}}$, Yi Wen ${ }^{\mathrm{b}}$ and Miao $\mathrm{Yu}^{\mathrm{c}}$ \\ School of Microelectronics and Solid-State Electronics, University of Electronic Science and \\ Technology of China, Chengdu 610054, China; \\ ajeffztyz@126.com, bwenyi169@163.com, creteryu@163.com
}

Keywords: College students; innovation and entrepreneurship; practical education; special education.

\begin{abstract}
In the current era when the difficult employment of college graduates is becoming increasingly prominent, promoting employment by starting a business is one of the important ways to solve the employment difficulty of college graduates. Therefore, the innovation and entrepreneurship education has become a very important course for undergraduates in school. However, on the one hand, because of the late start of the innovation and entrepreneurship education for college students in our country, on the other hand, after investigation, there are some problems in the innovation and entrepreneurship education for university students. Combined with the investigation and research, this paper gives some proposals for college students' innovation and entrepreneurship education from several aspects.
\end{abstract}

\section{浅谈大学生创新创业教育}

\section{武剑, 文译，于沝}

微电子与固体电子学院, 电子科技大学, 成都, 中国

摘要: 在目前大学生就业难日益突出的时代, 以创业促就业是一种可以很好解决大学生就业 难的重要途径之一，因此大学生创新创业教育就成为大学生在校期间一项很重要的课程。但 是一方面由于我国大学生创新创业教育起步较晚, 另一方面经过调研, 目前我国高校大学 生创新创业教育存在一些问题。结合调研情况, 本文从几个方面给出了一些高校大学生创 新创业教育的建议。

\section{关键词：大学生；创新创业；实践教育; 特色教育}

\section{1. 前言}

创新创业教育可以追溯到上个世纪早期, 美国在1919年就开始开设创业类的教育课程。德 国也于1950年筹备建立了“模拟公司”，探索出了在当时非常有影响力的创业实践教学法。澳 大利亚则非常重视小企业的创业教育, 成立专门的机构开展针对如何创立小企业的教育活 动。在亚洲范围内, 印度根据本国国情, 在1966年就提出了“自我就业教育”的理念, 鼓励毕 业生积极开展创业活动。1994年，日本在他们的教学中开设了一种名叫“综合学科”的课程, 其中学生必须至少修一门创业类的课程。Peter Drucker提出创业的能力跟基因毫无关系, 是 可以学习得到的。1989年11月，联合国教科文组织在北京召开的“面向21世纪教育国际研讨 会”上, 柯林博尔(Kelin-boer)在向世界经合组织(OECD)提交的一份报告中明确提出了“创业教 育”一词。他认为“创业教育”是未来人们除了学术性和职业性之外应学习和掌握的第三本教育 护照。至此, 创业教育这一概念正式出现 ${ }^{[1]}$ 。

1990年，我国的创新创业教育拉开了序幕，高校和机构陆陆续续开展了就业创业教育的基 础教育项目研究。但是根据有关调查显示, “在我国创业者群体中, 具有大学学历的创业者在 
仅占 $3.7 \%$, 而发达国家一般占 $20 \%-30 \%$ ”, 这说明我国高校的创新创业教育尚处于起步阶段, 其系统性、科学性和可操作性还不够完善 ${ }^{[2]}$ 。

近些年, 我国高校的大学生创新创业教育取得了飞速的发展, 但是整体上还存在不少问题, 譬如大学生创新创业教育认识还不是很到位、师资建设不完善、理论体系不健全、理论实践 结合不紧密、文化氛围不浓厚、专业特色不突出、开展范围不广泛等。目前, 我国的一些高 校采取的一种比较普遍的形式是围绕着“互联网+”、“挑战杯”等大赛, 运用第二课堂开展大学 生创新创业教育，但这种创新创业教育的受众面较小，不能惠及到绝大多数的学生。

我国2010年毕业大学生为631万, 到了2014年, 毕业大学生已经达到700多万, 年增长近3\%, 再加上往年尚未找到工作的大学生, 每年已经有超过700万的大学生在寻求工作岗位。于此 同时, 2016年考研报名人数 177 万, 比 2015 年增长约 12 万人, 而 2016 年研究生招生计划总人 数为 51.72 万人, 录取比例约为 $29 \%$ 。再加上受 2008 年美国经融危机影响, 我国就业岗位减少, 虽经济有复苏的趋势, 但是找工作大学生的人数与工作岗位数还是有很大的差距, 大学生就 业难问题愈发突出。因此, 鼓励大学生以创业的形式实现就业, 以创业带动就业, 创造更多 的就业岗位, 已经成为国家解决大学生就业难问题的重要途径之一。

\section{2. 大学生创新创业教育的问题}

因为我国高校创新创业教育起步较晚，仍处于探索阶段，还未形成完善的教育培养体系。 据调查, 在我国 107所“211”工程高校中, 仅有41所高校开设了创业相关的课程, 而且很多高 校提供的课程非常有限, 甚至仅仅局限于一门《创业管理》或《大学生就业与创业指导》课 程, 很难满足大学生创业理论学习和创业技能训练的需要” "[3]。因此, 创新创业教育和指导还 存在诸多问题。

\section{1 认识不到位}

2015年5月教育部发布的《关于做好2016届全国普通高等学校毕业生就业创业工作的通知》 中明确要求, 从2016年起所有高校都要设置创新创业教育课程, 并纳入学分管理。但是我国 的创新创业教育发展尚不完善, 我们的创新创业教育经历了从创业教育到创新创业教育的过 程, 同时创业教育的主要动力是来自于缓解大学生就业难的环境压力, 而不是来自于大学生 的内动力。所以, 虽然创新创业教育已经被纳入到学分体系中, 但实际情况是, 许多高校缺 乏创新创业的体系, 认识不明确。教育的形式也只是停留在讲座、比赛、小规模的实践等基 础层面上。

其次, 由于我国的教育模式, 从小学到中学采取的是传统的应试教育, 学生习惯于被动接 受, 并不适应主动寻找机会。进入大学以后, 学生对创新创业的理解和认识导致他们无法认 识到创新创业在他们人生发展中的重要性。以此同时, 在我国高校创新创业教育的理念一直 都是“精英化”，在这一理念的影响下，很多高校的创新创业教育只关注到少部分的大学生, 尤其是具有一定专业特长的理工科学生。这就使得以人文社会学科为代表的非理工科学生被 排斥在创新创业教育的相关活动之外, 很少甚至无法享受创新创业教育带来的红利, 创新创 业教育面“普适性”、“全面性”的理念也就无从谈起了。

\section{2 体系不完善}

根据教育部2015年10月发布的数据, 全国有 $82 \%$ 的高校开设了创新创业课程, 但 2015 年 11 月东北师范大学发布的《中国大学生就业创业发展报告2015-2016》显示, 大学生创业者中仅 有 $17.43 \%$ 主要从学校获得创业知识。由此可以推断, 目前创新创业教育课程体系内容匮乏、 缺乏实践设计、没有统一的教学大纲、教学效果不理想。

\section{3 资金不充足}

创新创业教育需要资金的大量投入才能有很好的实践平台, 实践是检验创新创业教育成果 的判定工具。同时, 相比其他创业者, 大学生经济不独立, 无固定经济来源。而且不论是贷 款还是投资人, 对大学生存在较大疑虑, 初创业的大学生风险很大, 一旦失败, 资金很难收 
回, 他们不愿为大学生提供资金。这就要求创新创业教育的实践及后续孵化环节必须有资金 的强力支持和配套服务 ${ }^{[4]}$ 。

\section{4 脱离实践}

目前的创新创业课程体系的设置大部分存在与现实生活脱节的现象。我国高校在推动创新 创业教育课程建设的过程中缺少与社会、企业等的衔接, 基本处于自己组织、自己开展、单 打独斗的状态。没有企业、社会在创新创业教育教学中的支持, 创新创业教育实践的空间和 机会就少之又少, 有了他们的支持, 就可以很轻松的让学生从课内走向课外、从校内走向企 业、从象牙塔走向社会, 为以后真正的创业奠定基础。

创新创业教育的“实践导向”本质要求高校搭建实践平台，推动高校创新创业教育的可持续 性发展。因此, 高校在推动创新创业教育的过程中, 就应该与企业、社会等外部机构搭起桥 梁, 全面开战实践教学, 有助于为学生提供理论联系实际的平台, 巩固所学知识, 将其运用 于企业实习锻炼、公益组织、社区机构等的需要, 同时也为学生提供一种实实在在的锻炼机 会, 浸入在企业和社会中, 培养他们敏锐的嗅觉和对创业的感知度, 这是一种双方受益的举 措。大学参与公益服务、当人社区义工等, 与社区、社会有更多的互动, 可以让学生在为社 区、社会提供良好服务的同时增强他们的专业技能、提升他们的综合素养，这就必然让他们 在就业中更具竞争力, 甚至可以更好的促进他们创业。在高校的实践中也表明, 曾经参与过 社区服务的学生具备更好的组织和管理能力, 在搜集资料和分析复杂事物方面的能力也比较 突出。

\section{3. 大学生创新创业教育的建议}

\section{1 扎实基础, 培养创新精神和科学素养}

为进一步扩大学生科技创新的受益面, 高校可以着力于将重大学科竞赛纳入到课程体系 中, 建设一批水平高、专业强、深受学生欢迎的理论与实践结合的课程, 从而在学生中形成 了一种追求真理、求实求真、勇于探索、崇尚科学、敢于实践的学术创新氛围。与此同时, 鼓励高校各学院结合自身的专业特色, 开展具有专业特色的“一院一赛”形式的竞赛活动, 进 一步为学生提供科技创新平台。同时, 完善学生科技创新活动结构、丰富学生科技创新平台, 加强学生动手能力培养和工程实践能力训练, 为培养学生创新精神和科学素养、持续推动创 新创业人才培养奠定了坚实的基础。

\section{2 深化改革, 打造特色创新创业教育}

必须坚守人才培养的核心使命, 依托学校学科的特色, 聚焦科技创新创业, 大力推进创新 创业教育。通过坚持创新创业教育全覆盖、坚持创新创业教育全过程、坚持创新创业教育全 链条、坚持创新创业资源全开放、坚持以科技创新为核心，构建起“教学产研”一体化的创新 创业体系。

首先, 深化人才培养改革, 把创新创业人才培养纳入根本定位。建立创新驱动、交叉培养、 协同育人的创新创业教育机制，强化“创新平台一学科竞赛一创业教育”多位一体的“普惠性” 创新与创业能力培养体系, 形成普及教育、实践教育、孵化教育“三位一体”的创新创业教育 体系。普及教育方面, 可以开设普适性创新创业课程、慕课、视频公开课等, 编写特色教材, 同时打造创新创业教育核心教师队伍; 实践教育方面, 着力构建创新实践体系与平台, 开展 创新创业训练、科技创新竞赛和创业比赛实践等活动, 以科技创新带动科技创业, 让创新应 用于创业, 让创业获得发展机会; 孵化教育方面, 点面结合, 分层次、分类型、科学化地实 施创新创业全过程教育, 形成了比较完善的创新创业教育和孵化体系。

其次, 创新创业教育也可形成“素质公选课——核心通识课——辅修专业——双学位” 覆盖 全部本科生的分层递进式教育教学体系, 支持教师、辅导员从多方位、多角度进行创新创业 教学活动探索, 面向全校学生开放实验室和实训平台; 组织实施“创新创业训练计划”; 以学 科竞赛构建“普惠性”科技创新竞赛体系, 提升学生科技创新能力; 以科技创新带动科技创业, 
举办“互联网+”大学生创新创业大赛等创新创业大赛, 全面满足各类学生的创新创业教育诉 求。

\section{3 协同创新，提供全方位创业指导服务}

为了确保创新创业教育取得实效, 需提供全方位的支持和保障服务。面向全体学生开展创 新创业教育, 面向学院开展创新创业指导工作, 面向具有强烈创业意愿的部分学生开展精英 教育。可以通过校院两级创新创业工作体系, 打造创新创业学生档案, 实现创新创业普及、 项目团队指导和创业种子精英培养。

从创新创业人才档案建设、顶级创业导师库搭建、创新创业资金保障、多方联动机制构建、 创业孵化服务升级和创业品牌活动打造等方面提供全方位的支撑保障服务。

\section{4 依托特色, 开创创新创业新天地}

按照高校创新创业教育的发展进程, 大致可以划分出四个阶段, 以学科竞赛为主要表现形 式的 1.0 , 以创新实践为主要表现形式的 2.0 , 以创新创业为主要表现形式的 3.0 版本, 以及以 学科特色的依托的 4.0 。但是无论在哪个阶段, 大学的创新创业要走掌握核心技术的路线, 核 心技术就是学校的学科特色。依托学科特色, 可以组建创新创业育成“ $1+1+1$ ”的模式, 即让 三五个学生前期碰撞、交流提出创新的思想和理念, 随后让青年导师加入团队进行引导, 最 后引入科技平台或大团队的软硬件资源作为支撑，从而提高大学生创业的成功率。

创新无止境，创业正当时。将学生的创新创业与国家的创新驱动发展战略、“一带一路”、 “一校一带”等形势有效结合起来, 推进创新创业的普及教育、实践教育、孵化教育, 努力培 养学生的创新创业能力, 促进大学生综合素质的整体提升。

\section{4. 创新创业教育的发展前景}

刘延东副总理在首届“互联网+”大学生创新创业大赛总决赛中讲道“创新创业, 是国家发展 之根, 是民族振兴之魂。今天的中国, 大众创业万众创新的时代潮流正在蓬勃涌动。我们要 找准高等教育改革发展定位, 切实增强深入推进高校创新创业教育改革的责任感紧迫感, 全 面提高人才培养质量，努力造就大众创业万众创新的生力军”。[5]

因此, 大学生的创新创业教育不仅是对大学生个人素质的提升, 更会极大促进我国社会的 发展。从创新创业教育着手, 进一步完善培养体系, 将大学生创新创业教育纳入本科生的培 养大纲中，为培养新时代高素质人才、实现民族的伟大复兴打好坚实的基础。

\section{References}

[1]. Shiping $\mathrm{Xu}$, Xianhua Shi et al. Review of the Research on Innovative Enterprise Education in Foreign Universities --A Discussion on the Approaches of Innovative Education in Chinese Universities [J]. Journal of Qujing Normal University. Vol. 35 (2016) No. 2, p. 22-26.

[2]. Hongmei Peng, Lili Zhan et al. Study on Innovation and Entrepreneurship Education Path for University Students [J]. Knowledge economy. Vol. 419 (2017) No. 5, p.162-162

[3]. Weiming Li, Chunyan Li, Xiaohua Du et al. Ten Years of Entrepreneurship Education in Chinese Universities: Evolution, Problems and System Construction [J]. Educational Research. (2013) No. 6, p.42-51

[4]. Jian Wu, Miao Yu, Yi Wen, Chuan Li. On Entrepreneurship Education of College Students Taking a University in the Southwest as an Example [J]. Western Quality Education. (2017) No. 2, p. 82-82.

[5]. Information on: http://www.moe.edu.cn/jyb_xwfb/moe_176/201510/t20151026_215488.html 